\title{
長期観察例における超音波計測結果よりみた 前立腺肥大症の進展機序
}

\begin{tabular}{|c|c|c|c|}
\hline \multirow{3}{*}{$\begin{array}{c}\text { 京都府立医科大学泌亦器科学教室 } \\
\text { (主渡辺 泱教授) }\end{array}$} & 大 & 西 & 克 \\
\hline & 大 & 江 & \\
\hline & 渡 & 辺 & \\
\hline
\end{tabular}

\section{DEVELOPMENT OF BENIGN PROSTATIC HYPERTROPHY ESTIMATED FROM ULTRASONIC MEASUREMENTS ON PATIENTS WITH LONG-TERM FOLLOW UP}

\author{
Katsumi Ohnishi, Hiroshi Ohe and Hiroki Watanabe \\ Department of Urology, Kyoto Prefectural University of Medicine \\ (Director: Prof. H. Watanabe)
}

Sixteen cases of benign prostatic hypertrophy $(\mathrm{BPH})$ have been followed up for 6-8 years by size measurements using transrectal ultrasonotomography. During the observation the weight of the prostate increased in 3 cases but in the remaining 13 it was almost stationary. There was a significant difference between these two patient groups. This means that the weight of hypertrophic prostate is not always increasing with age and suggests that the enlargement of the hypertrophic prostate may occur only in rather short duration.

The distribution of Presumed Circle Area (PCAR) on the horizontal section of the prostate in 16 cases was separated clearly into 2 groups with PCAR over and under 0.80 . The former group with high PCAR over 0.80 without significant residual urine should be followed up carefully to clarify the mechanism of urinary disturbance in BPH cases.

要旨：われわれは，経直腸的超音波断層法による超音波計測を用いて，前立腺肥大症患者 16 症例の長期 （最低 6 年, 最高 8 年)観察を行つた。この 16 症例の経直腸的超音波断層像を検討し, 以下の知見を得た.

1）前立腺肥大症長期経過観察において, 16症例中 3 例の前立腺重量はほ济連続的に増加し, 残り13例 は，その前立腺重量にあまり変化はみられなかった。

2）肥大症前立腺重量の加齢による推移をみると，重量の増加した 3 例はいずれす60歳代であり，70歳 代の症例は扮拈むね重量に変化はなかった。これは, 肥大症前立腺重量は加齢により常に増加しつづけ るといら従来の常識的な考えに反するものであった.

3） 16症例の経直腸的超音波断層像の仮想円面積比の年次的推移を検討する 界線として，常にそれよりも大きい症例群と常に0.8より小さい症例群に明確に分けられた。従来より, 仮想円面積比が 0.75 以上の前立腺肥大症症例でありながら, 病的残尿を生じないものが多数あることが 論じられてきたが，今回われわれが観察した中で仮想円面積比が常に 0.8 以上であるといら症例群が，ま さにこの症例に相当する。この病的残尿発生に対して高い potential をもった症例群を今後もさらに経 過観察していくことは，前立腺肥大症の排尿障害の病態を知る上で必要であることを認識した.

\section{緒 砉}

昭和42年, 渡辺ら ${ }^{1)}$ 開発した経直腸的超音波断層 法の出現により，その形態計測を用いて，前立腺の正 確な大きさや形状について客観的に知ることができる
ようになった。経直腸的超音波断層法を用いた前立腺 形態計測の応用は, 前立腺肥大症に扔いて, 推定重量 測定のほか，仮想円面積比による排尿障害の推定 ${ }^{2)}$, TUR 切除重量の予想, 薬物治療効果の判定などにひ 
ろく行われている。

今回, われわれは，この超音波計測を用いて，前立 腺肥大症長期観察 16 症例について経直腸的超音波断層 像の検討を行い, 形態学的側面より肥大症前立腺の加 歯による推移に関する興味ある知見を得たので，若干 の考察を加えて報告する.

\section{対象および方法}

排尿困難を主訴として，京都府立医科大学附属病院 泌尿器科外来を受診し, 臨床症状捛よび経直腸的超音 波断層法を含む諸検査成績より前立腺肥大症と診断さ れた男性患者のうち, 初診が昭和51年より53年の間で, かつ，現在（昭和58年 8 月末）まで保存的療法にて経 過観察している16症例を対象とした。保存的療法とし ては，主としてホルモン剤以外の通常の内服薬投与を 行い，随時残尿を測定した。観察期間は，最低 6 年, 最高 8 年でありその間の各症例の経直腸的超音波断層 法の施行回数は, 最低 2 回, 最高 9 回であつた。症例 の年齢構成は， 50 歳代 2 人， 60 歳代 4 人， 70 歳代 10 人 であった。

経直腸的超音波断層法には，経直腸的走查専用装

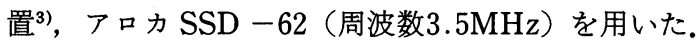
探触子を $5 \mathrm{~mm}$ 打きに引き抜きながら, 前立腺水平断面 像を $35 \mathrm{~mm}$ カメラで撮影し, 得られた前立腺断層像よ り各断面積を求め, 渡辺ら ${ }^{4)}$ の方法に従い, 各症例につ いて，前立腺推定重量を測定した。なお，前立腺超音 波計測による推定重量測定による誤差は，理論上も実 際上も $5 \%$ 以下であることが証明されている4).

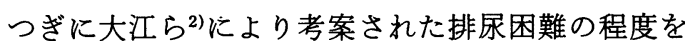
示すパラメーターである仮想円面積比を, 各症例につ いて算出した. 前立腺肥大症患者の前立腺水平断面は, 腺腫の発育成長に従って变化し, 初期は半月形である が，病期が進むに従って丸味を帯び，晚期には次第に 円形に近づくこの前立腺断面がいかに円に近いかを 具体的な数值として表現したものが，仮想円面積比で ある(図 1)。

\section{結 果}

今回，経過観察した前立腺肥大症患者 16 症例の年齢 と, 観察期間中の前立腺推定重量, 仮想円面積比の平 均値と標準偏差を，表 1 に示した。

16症例の肥大症前立腺の推定重量および仮想円面積 比の年次的推移を図 2 , 図 3 に示した。観察期間中, 症例 16 を除いて, 他の 15 症例の残尿は常に $30 \mathrm{ml}$ 以下で あった。

図 2 において，前立腺重量が，経過観察の間にどれ

図 1 仮想円面積比.

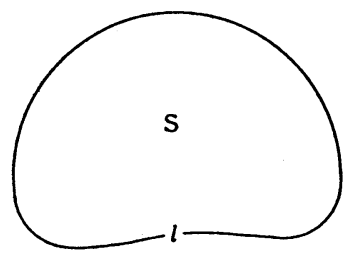

面臨が最大の前立腺水平断面缘 実腙の断面程: $5 \mathrm{~cm}^{2}$ 被膜周囲の長さ: $l \mathrm{~cm}$ 仮想円面槕：（周四の長さ しを有する仮想円の面税） $S^{\prime}=\pi\left(\frac{l}{2 \pi}\right)^{2}$

仮想円面䅡比 $\mathrm{PCAR}=\mathrm{S} / \mathrm{S}^{\prime}$

図 2 前立腺肥大症16例の前立腺重量の年次的推移.

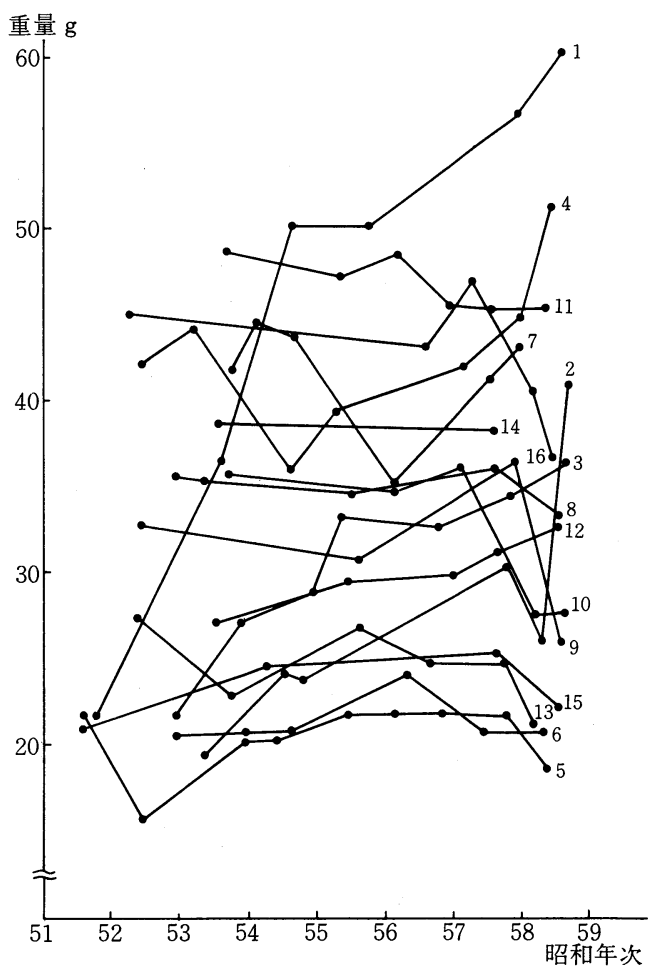

だけ増減したかについて，各症例の年次的推移の最初 と最後の前立腺重量の差と, 最初の前立腺重量の比 （\%）で各々比較した（表 1）。この比を前立腺重量増 加率とする。症例 $1 ， 2 ， 3 ， 4 ， 6 ， 7 ， 12 ， 15$ の 前立腺重量増加率は正の値であった。すなわちこれら は，観察の最初のころに比べて，現在の重量が最終的 
表 1 経直腸的超音波断層法により得られた 16 症例の超音波計測結果。

\begin{tabular}{|c|c|c|c|c|c|c|c|c|c|}
\hline \multirow{2}{*}{ 襎例号 } & \multirow{2}{*}{ 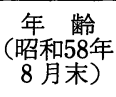 } & \multicolumn{5}{|c|}{ 前立腺重 量 } & \multicolumn{3}{|c|}{ 仮 想 円面積 比 } \\
\hline & & 初 回 & 終 回 & 增加 & 率 & 計測全回の平均 & 初 回 & 終 回 & 計測全回の平均 \\
\hline 1 & 68 & $21.6 \mathrm{~g}$ & $60.6 \mathrm{~g}$ & $181 \%$ & 増 & $46.0 \mathrm{~g} \pm 13.3 \mathrm{~g}$ & 0.82 & 0.93 & $0.86 \pm 0.04$ \\
\hline 2 & 61 & 19.9 & 41.1 & 118 & 加 & $27.5 \pm 7.1$ & 0.55 & 0.60 & $0.70 \pm 0.09$ \\
\hline 3 & 70 & 21.8 & 36.3 & 67 & 群 & $30.6 \pm 4.6$ & 0.60 & 0.79 & $0.72 \pm 0.06$ \\
\hline 4 & 77 & 42.0 & 51.3 & 22 & & $42.8 \pm 4.5$ & 0.84 & 0.91 & $0.91 \pm 0.04$ \\
\hline 5 & 79 & 21.8 & 18.4 & -16 & & $20.4 \pm 2.0$ & 0.73 & 0.73 & $0.69 \pm 0.06$ \\
\hline 6 & 76 & 20.5 & 20.8 & 1 & & $21.3 \pm 1.2$ & 0.59 & 0.73 & $0.67 \pm 0.05$ \\
\hline 7 & 75 & 41.8 & 43.1 & 3 & & $41.6 \pm 3.1$ & 0.87 & 0.85 & $0.88 \pm 0.02$ \\
\hline 8 & 76 & 35.6 & 33.3 & -6 & 不 & $34.9 \pm 0.9$ & 0.82 & 0.88 & $0.85 \pm 0.03$ \\
\hline 9 & 56 & 32.8 & 25.6 & -22 & & $31.4 \pm 3.9$ & 0.61 & 0.75 & $0.66 \pm 0.06$ \\
\hline 10 & 67 & 35.8 & 27.4 & -24 & 変 & $32.4 \pm 4.2$ & 0.90 & 0.87 & $0.87 \pm 0.05$ \\
\hline 11 & 79 & 48.6 & 45.5 & -6 & & $46.8 \pm 1.3$ & 0.81 & 0.80 & $0.83 \pm 0.03$ \\
\hline 12 & 77 & 27.0 & 32.8 & 21 & 群 & $30.1 \pm 1.9$ & 0.88 & 0.88 & $0.86 \pm 0.02$ \\
\hline 13 & 69 & 27.2 & 20.8 & -24 & & $24.5 \pm 2.2$ & 0.82 & 0.86 & $0.84 \pm 0.01$ \\
\hline 14 & 73 & 38.3 & 38.0 & -1 & & $38.2 \pm 0.2$ & 0.92 & 0.94 & $0.93 \pm 0.01$ \\
\hline 15 & 78 & 21.5 & 21.9 & 2 & & $23.3 \pm 1.6$ & 0.90 & 0.81 & $0.89 \pm 0.05$ \\
\hline 16 & 58 & 45.0 & 38.4 & -15 & & $42.9 \pm 3.2$ & 0.78 & 0.77 & $0.86 \pm 0.07$ \\
\hline
\end{tabular}

図 3 前立腺肥大症16例の仮想円面積比の年次的推 移.

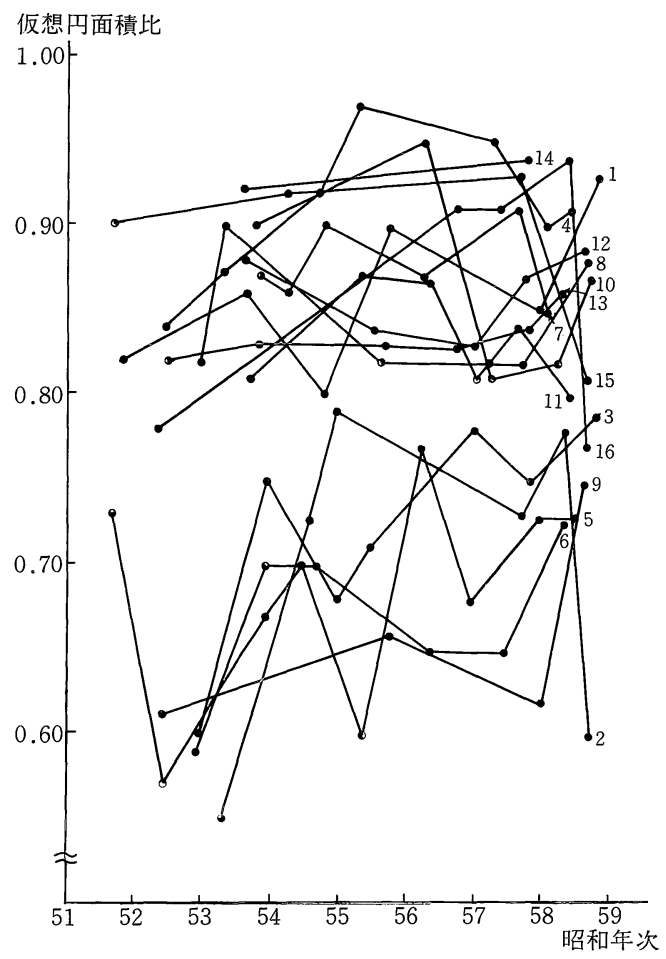

に増加している症例群であった。また症例 $5 ， 8 ， 9$ ， $10 ， 11 ， 13 ， 14 ， 16$ 前立腺重量増加率は負の值であっ た。すなわちこれらは, 前立腺重量が最終的に減少し
ている症例群であった。しかし50\%以内の増減を境界 として考学ると, 症例 1，2，3 は，初診時より現在 まで，前立腺重量が境界以上に増加しているが，他の 13症例は，境界以上の増減はみられなかったことにな る. 前者（症例 1,2 打よび 3 ）を増加群, 後者（他 の13症例）を不変群と呼ぶことにする。

図 4 は，経過観察中に急激に前立腺重量が増加した 増加群に属する症例 1 の, 初回と終回の経直腸的超音 波断層像を比較したものである。図 5 は，不変群に属 する症例 8 の, やはり初回之終回の経直腸的超音波断 層像を比較したものである。

つぎに，全症例の前立腺重量の年齢的推移を図 6 に 示す。この図をみると，増加群はいずれる60歳代であ り，70歳代の症例は，打打むね不変群に属することが わかる。

図 3 は，16症例の仮想円面積比の年次的推移を示す ものであるが，症例16以外の全症例は，仮想円面積比

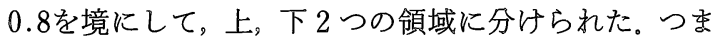
り,ある症例の前立腺の仮想円面積比が 0.8 以上であれ ば，観察期間中，常にその症例は 0.8 以上であり，0.8 以下の症例では常に 0.8 以下であった。このように，観 察肥大症前立腺の仮想円面積比は, 0.8 境界線を拈互 い踏み越えることは決してなかった。

ここで，われわれは仮想円面積比が排尿障害の程度 を示すパラメーターであることを考慮し，肥大症前立 腺が病的残存を発生する potential をどの程度もつか 
図 4 症例 1 の初回の終回の経直腸的超音波断層像.

M. K. 68y.o.

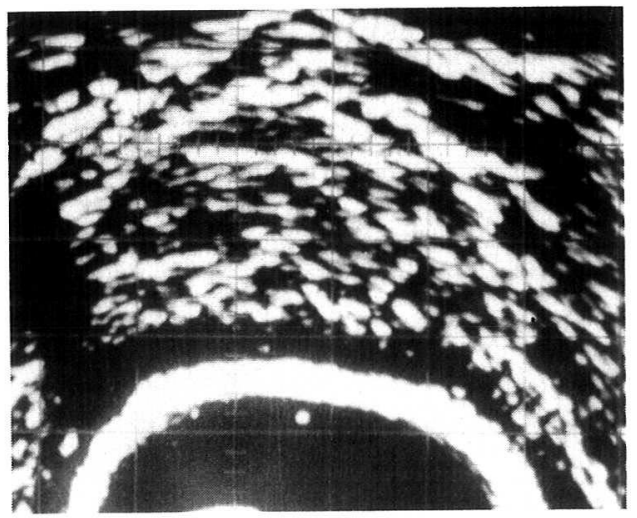

51.10 .15

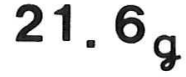

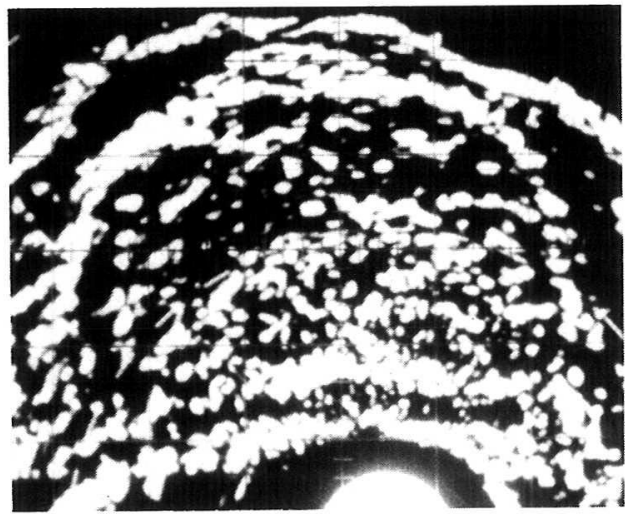

58. 8.12
$60.6 \mathrm{~g}$

図 5 症例 8 の初回と終回の経直腸的超音波断層像。

B.Y. 76 y.o.

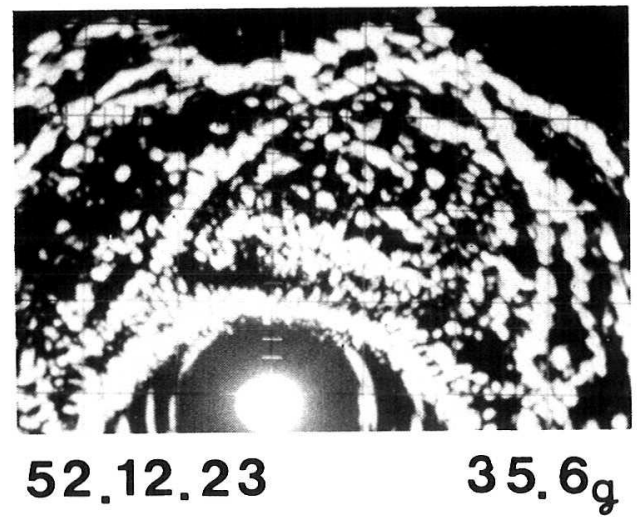

という意味で, この 2 つ症例群をそれぞれ, low potential group (仮想円面積比 0.8 以下), high potential group（仮想円面積比 0.8 以上）とした。 high potential group は, 症例 $1,4,7,8,10,11,12$, 13，14，15であり， low potential groupは, 症例 2 , $3 ， 5 ， 6 ， 9$ であった。

ただし，症例16は，例外的に $2 つ の$ groupにまた

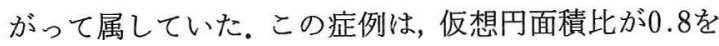
越えた時点で，手術適応を示す残尿 $80 \mathrm{ml}$ を発生した が，事情により手術せず，さらに経過を観察していた ところ, 現在は再度仮想円面積比が 0.8 を割り, 残存も $15 \mathrm{ml}$ と減少したものである。

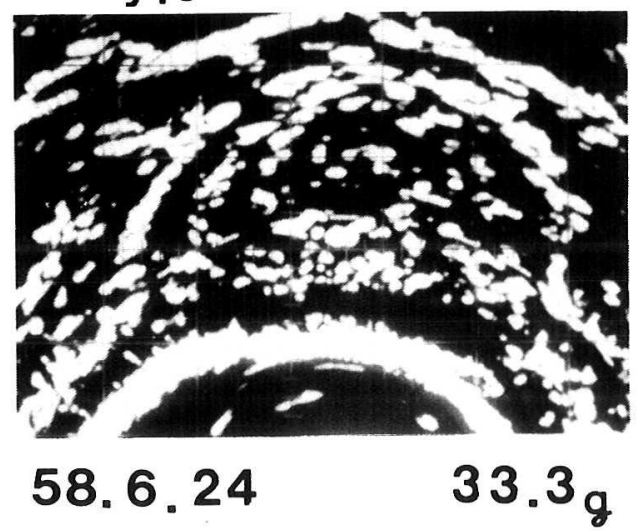

考察

前立腺は, 男子附属器のひとつとして生殖に大きく 関与して扔り,加龄とともにその大ささを変化させる。 身体の発育, 成長につれて前立腺は成熟し, 生殖器と して役割を果たしたのち，正常前立腺は萎縮していく ことになるが，肥大症として増殖性変化を示す前立腺 は，壮年期より加齢とともに大きさを増していく。 Flocks ${ }^{5}$ によれば, 60歳代男子の65\%に, 70歳代男子の $70 \%$ ，肥大症による何らかの症状があり，そのらち の $1 / 3 か ゙$ 治療を要するといら。またわれわれの前立腺集 団検診の成績によれば，55歳以上の男子の $32 \%$ ，前 立腺肥大症が発見されている 
図 6 前立腺肥大症16例の前立腺重量の年齢的推移.

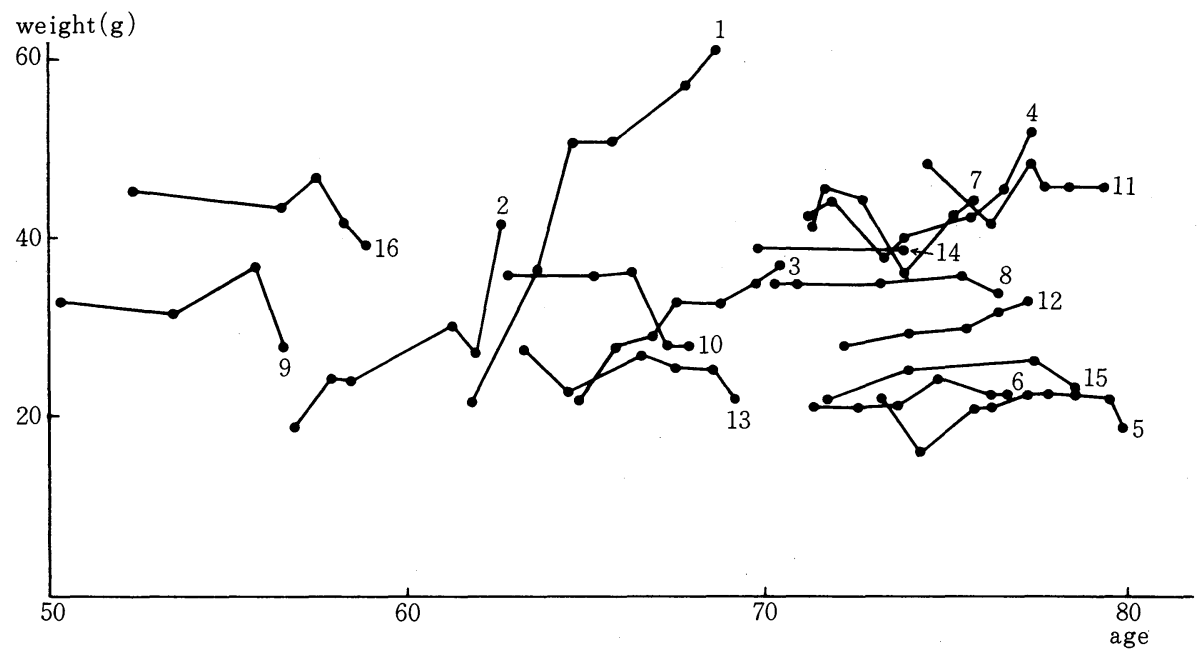

Moore $^{7)}$ や Swyer ${ }^{8)}$ は, 多数例の剖検による詳細な病 理組織学的検討から, 各年齢層の前立腺の大きさを測 定し, 前立腺重量の加龄による推移を示した。

前立腺は, 骨盤内臟器として骨盤内の奥深くに存在 するため, 古来, 生体の前立腺の大きさ測定に対する 正確な検査法はなく, 生体前立腺の大きさの加柃によ る推移を正確に求めることはきわめて困難であっ た。 ${ }^{910)}$. しかし, 昭和 42 年より渡辺ら ${ }^{3)}$ が実用化, 発 展させてきた経直腸的超音波断層法を用いることで， 生体前立腺に関する豊富な情報を容易に手に入れるこ とができるようになった。

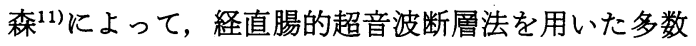
例の正常生体前立腺の加齢による大きさの推移が報告 されているが, 今回, われわれは, 実際前立腺肥大症 として治療中の患者に扣いて，前立腺の大きさの加齢 による推移を，経直腸的超音波断層法を用いてそれぞ れ数年にわたり経過観察したわけである.

森の経直腸的超音波断層法による348例の正常前立 腺の重量計測の結果によれば11), 正常前立腺は, 11〜15 歳で $9.0 \mathrm{~g}$ と極めて小さいが, $16 \sim 20$ 歳で $17.8 \mathrm{~g}$ とほぼ 2 倍に増加し, 21 25歳では $19.8 \mathrm{~g}$ と最高值に達する. 青壮年期ではほぼ一定の大きさを維持するが，41〜 45 歳で一過性のピークを示した後, 51歳頃より徐々に減 少しはじめ 66 70歳で $13.8 \mathrm{~g}$ に減少し, それ以後は $12.0 \mathrm{~g}$ 前後に落ち着くという（図 7 ).

また, Swyer の192例の剖検前立腺に打ける年齢一 重量曲線によれば8)（図 8 ）, 前立腺重量は45歳頃より 2 相性となり, 病理組織学的に正常な例では, 萎縮の
図 7 正常前立腺重量の加龄による推移（森による）.

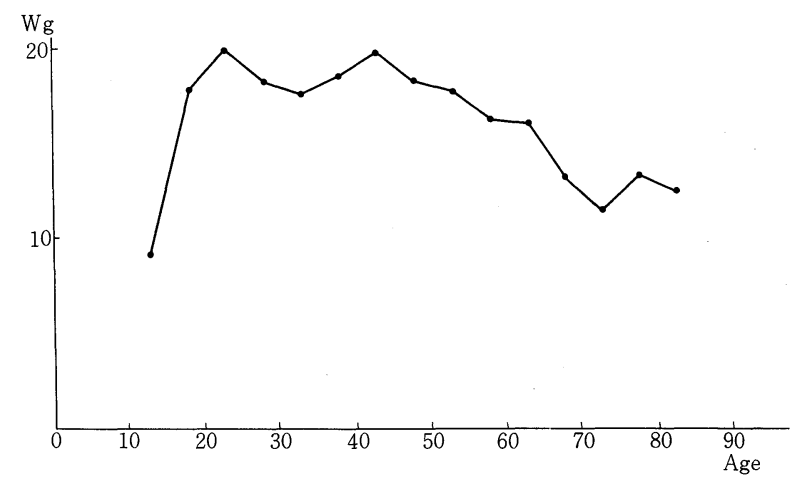

図 8 Swyer の年齢一重量曲線.

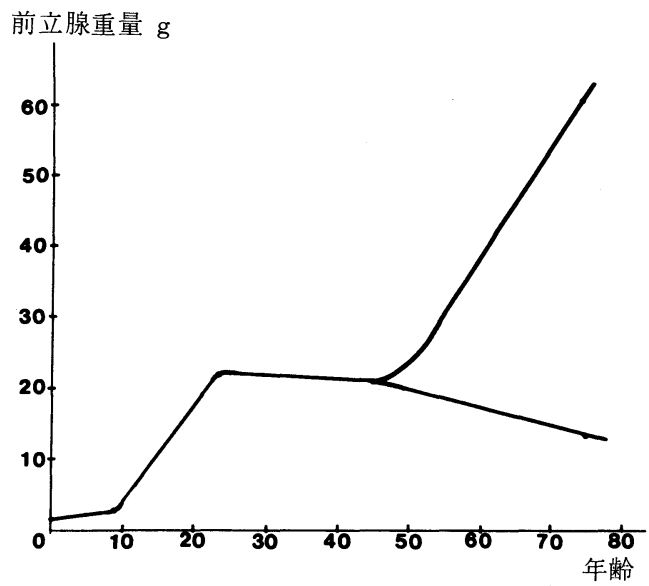


ため徐々に重量は减少するが，肥大症例では，重量が 連続的に増加するとのことである.

ところが，今回のわれわれの計測結果では，重量の 年龄的推移に招いて, 重量の増加群は16例中 3 例にす ぎず，不変群が残りの13例と，大部分を占めた。この 事実は, 上で述べた Swyer の剖検による前立腺重量の 加齢による推移で示されるよらな, 肥大症前立腺重量 は加齢とともに連続的に増加するという従来の常識的 な考壳に反するものである．統計学的に有意であるた めには，も5少し症例を重ねなければならないであろ らが，増加群が 3 例とも 60 歳代であること，70歳代の 症例がすべて不变群であること（図 6 ）より考克，以 下の推測が成り立つ。すなわち，肥大症前立腺は，50 歳代から60歳代にかけてその重量が急速に増加する が，その間に臨床的に手術適応とならない場合は，あ る時点より後は打打むねそれ以上重量が増加せず，長 期にわたって一定の大きさを保つのではないかという 推測である.

いいかえると，前立腺肥大症といら現象は，これま で誰でもが考えてきたように，中年から老年の時期に 長期間をかけて徐々に起こるといらのではなく，中年 あるいは初老のある時期に，比較的短時日の間に急速 に発生し，完成してしまい，それ以後はもら進展しな いといら考方方である，この急速に肥大症が完成する のに要する時間を, 本研究における増加群の結果より 大胆に予測するならば， 2 ないし 5 年といら数字が一 応挙げられる（因 6 )。

実際日常の臨床において，きわめて大きな肥大症を 有する患者に自覚症状が始まつた時期をたずねると， 数カ月とか半年とかいら意外に短い病歴を答えるのに 驚かされた記憶は，泌尿器科医なら誰でももっている のではなからうか．前立腺肥大症は50歳代，60歳代の ある時点で突然に始まり，数年を経ずして病態が完成 してしまうといらわれわれの仮説には，かなりの信頼 性があるといってよさそうである。

前立腺重量が，初診時より減少してきている症例に 関しては，その原因を今後継続して検討する必要があ る.しかし前立腺炎などにおいては，前立腺重量は数 日の間に数十\%变動してしまうこともそれ汪ど稀では ないので，前立腺肥大症の場合も，そのような常在的 な重量の日差变動を考慮しなければならないのかもし れない。

また, 症例 1 のように, 仮想円面積比が初診的より かなり高くなり, 重量も約 3 倍に増加しているにもか
かわらず,病的残尿を示さない症例が存在することは, 前立腺肥大症の排尿障害の程度が，前立腺の大きさや 水平断面の丸さかげんだけでなく，これらとは異なっ た第 3 の factor に左右されていることを示唆して拈 り,きわめて興味深い。

大江らの報告 ${ }^{2)}$ とれば，肥大症前立腺で仮想円面 積比が 0.75 以下の場合はほとんどの症例が残尿 $30 \mathrm{ml}$

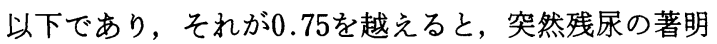
な増加が始まり，特に尿閉は仮想円面積比 0.75 以上の 症例にのみ認められるという，排尿障害の程度を示す パラメーターとして, 提唱されたのが, 仮想円面積比 であるが，これが，1.0に近づく，すなわち，前立腺断 面が円に近づくといらことは, 内腺である腺腫が成長 して, 外科的被膜と尿道の両方を均等に強く圧迫して いくことであるから，この強い圧迫を受け，尿道内圧 は上昇するはずである。これによって，排尿時の尿道 抵抗は増加し，排尿はさらに障害されることになる。 小島ら ${ }^{12)}$ は, 前立腺肥大症に拈ける経直腸的超音波断 層法と尿道内圧曲線の比較検討を行い，実際，仮想円 面積比が尿道内圧をよく反映していることを証明して いる.

病的残尿が発生するためには，仮想円面積比が 0.75 以上である必要があるが，この逆は成り立たない。す なわち，仮想円面積比が 0.75 以上でも病的残尿のない 症例はずいぶん多い，今回，われわれが観察した前立 腺肥大症患者の仮想円面積比の年次的推移を示す図 （因 3 ）に招いて, high potetial group に属する症例 は, まさに大江ら ${ }^{2)}$ の述べた仮想円面積比 0.75 以上で

因 9 前立腺肥大症患者の経過を示す模式困

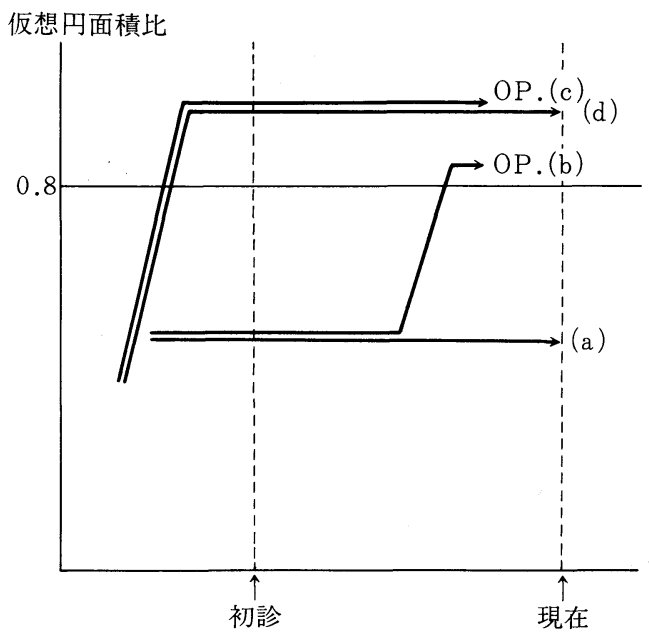


かつ病的残存を示さない前立腺肥大症例群に相当す る.

一方, 経過観察の間に, 仮想円面積比が 0.75 以下か ら急速に増大し, 0.8 境界線を越えた症例はかなりあ ることが想像されるが，このような症例はすべて必ず 病的残尿を発生して手術適応となってしまい, 今回の 長期観察症例群からはdrop out したものと考兄られ る.

以上の事実から，以下のことが推察される。すなわ ち，前立腺肥大症患者に扣いては，仮想円面積比が小 さい(0.75 0.8以下) 万ちに，刺激症状を訴兄て泌尿 器科を受診する場合と，仮想円面積比がすでに十分大 きくなった $(0.75 \sim 0.8$ 以上)後に訪れる場合とがある. そして前者の場合は，（a）経過観察期間を通じて仮想 円面積比が $0.75 \sim 0.8$ 越えない症例と，（b ）仮想円 面積比が一定期間のらちに0.75 0.8を越えてしまう 症例があり，この（b）情必ず病的残尿を発生する。 また後者の場合は, (c) 初診時すでに病的残尿を有し ている症例と, (d) 病的残尿発生の potenial は有し たま病的残尿発生が “休止”している症例がある（図 9 ).

これらのらち，(b) および (c) の症例は手術が適 応となるので長期観察は行われず，今回対象とされた ものは（a）拈よび（d）に属する症例のみであった といらことになる。 それが図 3 とおいて，仮想円面積 比0.75〜0.8の帯域に空白が生じた理由である.

(a)，(b)，(c) の 3 群に㧤いては，その病的残尿発 生の有無が仮想円面積比の理論からよく説明できる. しかしわからないのは (d) 群, すなわち今回の長期観 察に怙いて high potetial group と定義された症例群 である。この群では, 前立腺の形態からは尿道に十分 圧が加わることが予想されるにもかかわらず，実際に はそれほどの圧がかからないために病的残尿がない。 この矛盾を解決するためには，肥大症前立腺の外科的 被膜や腺腫の物理的諸性質を知ることが必要であると 思われ，われわれは現在，それらを鋭意検討中である。

いずれにせよ，仮想円面積比が高い前立腺に扔いて， 病的残尿を生じる場合とそうでない場合があるという 問題は, 前立腺肥大症の病態生理の本質に迫る重要課
題であり，その解明が強く望をれる。

\section{結 語}

経直腸的超音波断層法を用いて，長期観察前立腺肥 大症16症例の前立腺推定重量, 仮想円面積比の年次的 推移を検討し, 前立腺肥大症の進展機序とその病態生 理について若干の考察を加え，報告した。

なお本論文の要旨は日本超音波医学会第43回研究発表会 （1983年12月，於福岡）に拈いて発表した。

\section{文献}

1) 渡辺 決, 加藤弘彰, 加藤哲郎, 森田昌良, 田中元 直, 寺沢良夫：超音波断層法に上る前立腺診断. 日 泌尿会誌，59，273-279， 1968.

2) 大江 宏, 斉藤雅人, 田中重喜, 板倉康啓, 渡辺 決：前立腺肥大症の超音波診断. (第 2 報). 前立腺 肥大症の成り立ちと仮想円面積比. 日超医論文集, $32-61,121-122,1977$.

3）渡辺 決：経直腸的超音波断層法の開発と応用. 日泌尿会誌，65，613-632，1974.

4）渡辺 決, 猪狩大隆, 海法裕男, 棚橋善克, 原田一 哉, 斉藤雅人：超音波断層法に上る前立腺計測. 西 日泌尿，37，222-232，1975.

5) Flocks, R.H.: Benign prostatic hypertrophy. Its diagnosis and management. Med. Times, 92, 519, 1964.

6）大江 宏, 渡辺 泱, 三品輝男, 斉藤雅人, 板倉康 啓, 中尾昌宏：前立腺の集団検診. 超音波医学, 10 , 360-365, 1983.

7) Moore, R.A.: Benign prostatic hypertrophy and carcinoma of the prostate. Surgery, 16, 152, 1944.

8) Swyer, G.I.M.: Post-natal growth changes in the human prostate. J. Anat., 79, 130, 1944.

9）黒田恭一：前立腺計測法. 日泌尿会誌, 43, 83-100, 1952.

10) Thumann, R.C.: Estimation of the weight of the hyperplastic prostate from the cystoureth. rogram. Am. J. Roent., 65, 593-595, 1951.

11）森 康行：正常前立腺の超音波計測. 日泌尿会誌, 73, 767-781, 1982.

12）小島宗門, 大西克実, 大江 宏, 渡辺 決：前立腺 肥大症に打ける経直腸的超音波々尿道内压曲線の 比較検討, ならびに尿水力学的評価. 日泌尿会誌, 投稿中.

（1984年 2 月 15 日受付） 